\title{
SURGERY FOR IDIOPATHIC FULL-THICKNESS MACULAR HOLES
}

\author{
ZDENEK J. GREGOR \\ London
}

\begin{abstract}
SUMMARY
Background: Idiopathic full-thickness macular holes (FTMH) are an important cause of loss of central vision in the elderly. Improved understanding of the natural history and pathophysiology of FTMH has led to recent advances in the surgical management of patients with this hitherto untreatable condition.

Methods: The current concepts of the natural history and surgical treatment are reviewed. Pilot studies of vitrectomy undertaken to relieve the tangential traction at the vitreomacular interface and the role of growth factors as promoters of a limited healing response are reviewed and illustrated by the results of surgical treatment of macular holes obtained by the author and others.

Results: Whereas early pilot studies of vitrectomy of impending (stage I) macular hole suggested beneficial results $(80-95 \%$ of operated eyes did not progress to FTMH), no such benefit could be demonstrated by a subsequent randomised treatment trial. In a study of early vitrectomy and partial fluid-gas exchange hole closure was achieved in $88 \%$ of patients with stage II FTMH with visual improvement in $67 \%$. In other studies of FTMH (stages II-IV) the addition of adjunctive substances such as growth factors, autologous serum, plasma or platelet concentrate has resulted in closure in $\mathbf{7 7 - 1 0 0 \%}$ of cases. However, similar results have also been reported with vitrectomy and gas tamponade alone. Histologically the closure of the FTMH is associated with glial proliferation.

Conclusion: Vitrectomy and intraocular tamponade appear to be beneficial in patients with FTMH. The role of adjunctive substances, such as growth factors and other promoters of the healing response, requires clarification by randomised treatment trials.
\end{abstract}

Idiopathic full-thickness macular holes (FTMH) are an important cause of loss of central vision in the

Presented in part at the Vitreous Symposium, Annual Congress of the Royal College of Ophthalmologists, 1995.

Correspondence to: Mr Zdenek J. Gregor, FRCS, FRCOphth, Moorfields Eye Hospital, City Road, London EC1V 2PD, UK. elderly. It is estimated that the condition affects 3 in 1000 individuals, $72 \%$ of whom are women, usually in their sixth or seventh decade of life. ${ }^{1}$ Hormonal imbalances $^{2}$ and high plasma fibrinogen ${ }^{3}$ have been noted in previous studies. There is now general agreement that vitreoretinal traction is all important in the development of FTMH., ${ }^{4,5}$

In 1988, Gass ${ }^{6}$ described his observations on the pathogenesis of FTMH and suggested a classification of FTMHs which is now widely used. He pointed out that unlike peripheral retinal breaks, FTMHs are caused by tangential vitreoretinal traction. Initially, a focal detachment of the foveola occurs (stage I or impending hole), which may resolve spontaneously in up to $60 \%$ of cases. ${ }^{7}$ In others the continuing traction results in disintegration of the fovea and the appearance of a small FTMH with an overlying vitreous condensation (stage II). With time the FTMH usually enlarges, the edges become elevated by a cuff of subretinal fluid and a localised posterior vitreous separation occurs with a condensation ('operculum') lying in front of the retina (stage III). Eventually, with further vitreous detachment, the 'operculum' moves forward on the posterior vitreous cortex and may become difficult to find ophthalmoscopically (stage IV).

The importance of traction at the vitreoretinal interface has been further highlighted by retrospective $^{6,8}$ and prospective ${ }^{9}$ studies. Using kinetic B-scan ultrasonography Fisher et al. ${ }^{9}$ demonstrated that in patients with an established FTMH in one eye, the fellow eye with attached vitreous has a $12 \%$ risk of developing a macular hole. In contrast, none the fellow eyes with posterior vitreous separation at baseline went on to develop a FTMH.

Until recently, the management of FTMHs was mostly limited to observation. However, since Gass's suggestion that vitrectomy may lead to the relief of vitreoretinal traction in the early stages of the macular hole, results of treatment of impending 
(stage I) macular holes ${ }^{10-12}$ and, more recently, of FTMH (stages II-IV) have been reported. ${ }^{13-19}$

\section{SURGICAL TREATMENT OF IMPENDING MACULAR HOLES}

Smiddy et $a{ }^{10}{ }^{10}$ first reported favourable results of surgical removal of the posterior cortical vitreous from the macular surface in 15 patients with impending (stage I) macular holes, with only $20 \%$ of their patients progressing to a FTMH. Similar results were obtained by Jost et al. ${ }^{11}$

In another pilot study of 40 consecutive patients with impending (stage I) macular holes in fellow eyes who had had FTMHs operated on at Moorfields Eye Hospital, ${ }^{12}$ the disease process was arrested in $95 \%$ of patients. In that study there were 24 women and 16 men aged 58-78 years (mean 68 years). The duration of symptoms in the operated eyes was between 2 and 12 weeks (mean duration 7 weeks). As in the previous reports, the operative procedure consisted of a three-port pars plana vitrectomy and peeling of the posterior cortical vitreous from the retinal surface using the aspiration cannula. No intraocular tamponade was used. After a minimum follow-up of 6 months, $2(5 \%)$ patients had progressed to FTMH. In the first patient this was observed on the first post-operative day and in the second 4 months after the operation. Central vision was preserved or improved in the remaining 38 (95\%) patients.

Although the results of such pilot studies appeared encouraging at first, they had to await confirmation by a controlled randomised treatment trial. In one such trial de Bustros et al. ${ }^{7}$ compared vitrectomy for stage I macular hole with its natural history and found no statistical difference in the anatomical or visual outcomes (Table I). However, as full recruitment to this trial could not be concluded prior to the publication of the results, no definite recommendations as to the management of impending (stage I) macular holes can be offered. Neverthless, with this information and with the encouraging results of surgery for FTMH, the management of impending (stage I) macular holes now tends to be less aggressive.

\section{SURGICAL TREATMENT OF FULL- THICKNESS MACULAR HOLES}

Natural history studies have confirmed that central vision of patients with an established FTMH tends to be poor, with the visual acuity usually stabilising at $6 / 36$ in $80 \%$ of patients. ${ }^{20}$ Occasionally, however, spontaneous closure of a FTMH may occur with a consequent improvement in vision. ${ }^{21}$ Histologically, such an event is characterised by the formation of an epiretinal membrane with the proliferation of glial and retinal pigment epithelial cells. ${ }^{22}$

Kelly and Wendel ${ }^{13}$ were the first to report successful surgical closure of FTMH in $58 \%$ of 52 patients operated on with vitrectomy, the removal of posterior vitreous cortex, epiretinal membrane dissection and fluid-gas exchange. The mean duration of symptoms in their patients was 1.5 years (range $0-30$ years). Visual improvement was noted in $42 \%$ of operated eyes. However, operative complications occurred in $15 \%$ of cases and these were thought to be related to the surgical manipulaton of the macula.

Encouraged by this report and in an attempt to minimise operative complications, a pilot study of patients presenting with a very short duration of symptoms (3 months or less) or FTMH in the fellow eye was carried out at Moorfields Eye Hospital. ${ }^{23}$ This group was chosen as surgical manipulation of macular holes in patients with a very short history was not deemed necessary. Twenty patients were entered, 10 of whom were female. Nine had stage II FTMH, 7 stage III and 4 stage IV FTMH. The minimum follow-up was 6 months. The operative technique consisted of pars plana vitrectomy and removal of the posterior vitreous cortex, but no macular manipulation, such as peeling of epiretinal membranes, was attempted. Partial fluid- $\mathrm{SF}_{6}$ gas exchange was performed and the patients were asked to remain in the face-down position for a minimum of 10 days. This simplified technique resulted in the closure of the FTMH in 8 of the $9(88 \%)$ patients with stage II holes, but only 2 of the $7(29 \%)$ patients

Table I. Results of surgical treatment for impending (stage I) macular holes

\begin{tabular}{|c|c|c|c|c|c|}
\hline \multirow[b]{3}{*}{ Procedure } & \multicolumn{5}{|c|}{ Study } \\
\hline & \multirow{2}{*}{$\frac{\text { Smiddy et al. }{ }^{10}}{\text { PPV and PVCR }}$} & \multirow{2}{*}{ 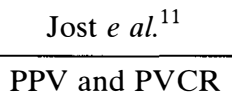 } & \multirow{2}{*}{$\frac{\text { Orr } \text { et } a l .{ }^{12}}{\text { PPV and PVCR }}$} & \multicolumn{2}{|c|}{ de Bustros et al. ${ }^{7}$} \\
\hline & & & & PPV and PVCR & Observation \\
\hline $\begin{array}{l}\text { No. of patients } \\
\text { (women : men) }\end{array}$ & $\begin{array}{c}15 \\
(12: 3)\end{array}$ & $\begin{array}{c}15 \\
(8: 7)\end{array}$ & $\begin{array}{c}40 \\
(24: 16)\end{array}$ & $\begin{array}{c}27 \\
(18: 9)\end{array}$ & $\begin{array}{c}35 \\
(27: 8)\end{array}$ \\
\hline Mean age (years) & 64 & 67 & 68 & 69 & 67 \\
\hline $\begin{array}{l}\text { Mean duration of symptoms } \\
\text { (weeks) }\end{array}$ & 26 & $\mathrm{~N} / \mathrm{K}$ & 7 & $<12$ & $<12$ \\
\hline $\begin{array}{l}\text { Mean duration of follow-up } \\
\text { (months) }\end{array}$ & 26 & 13 & 36 & 17 & 17 \\
\hline Progression to full-thickness hole & $3 / 15(20 \%)$ & $3 / 15(20 \%)$ & $2 / 40(5 \%)$ & $10.27(37 \%)$ & $14 / 35(40 \%)$ \\
\hline Type of study & Pilot & Pilot & Pilot & Randor & d trial \\
\hline
\end{tabular}

PPV, pars plana vitrectomy; PVCR, posterior vitreous cortex removal; N/K, not known. 


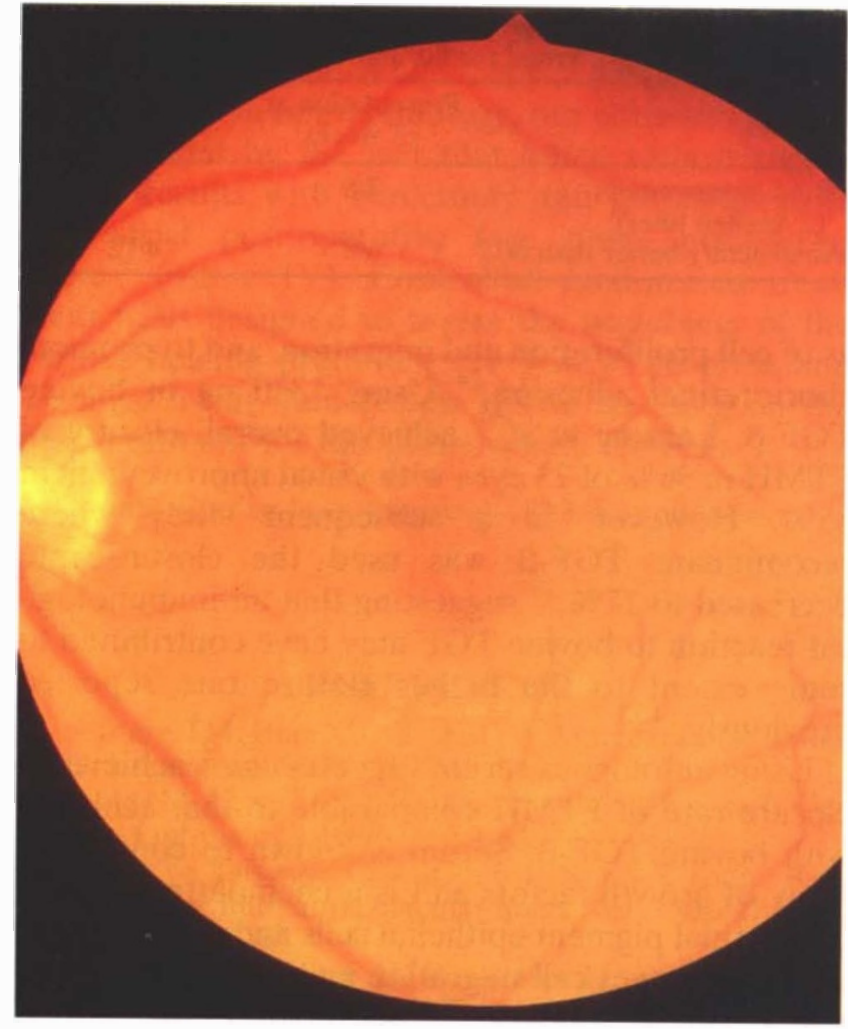

(a)

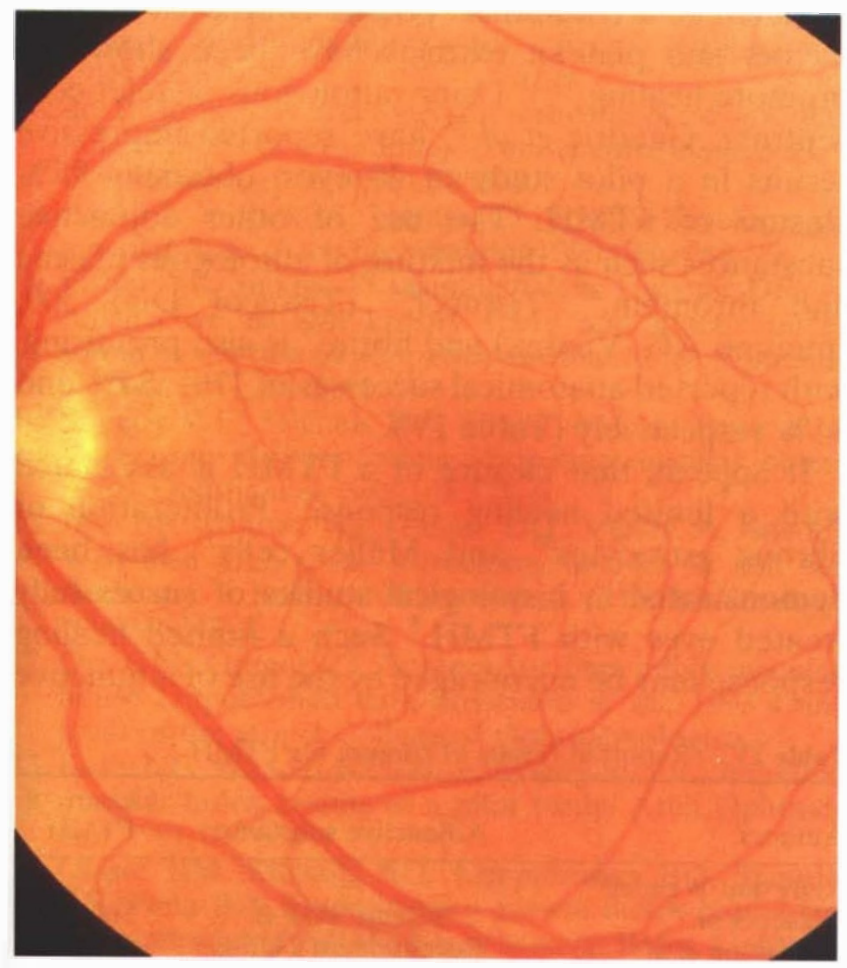

(c)

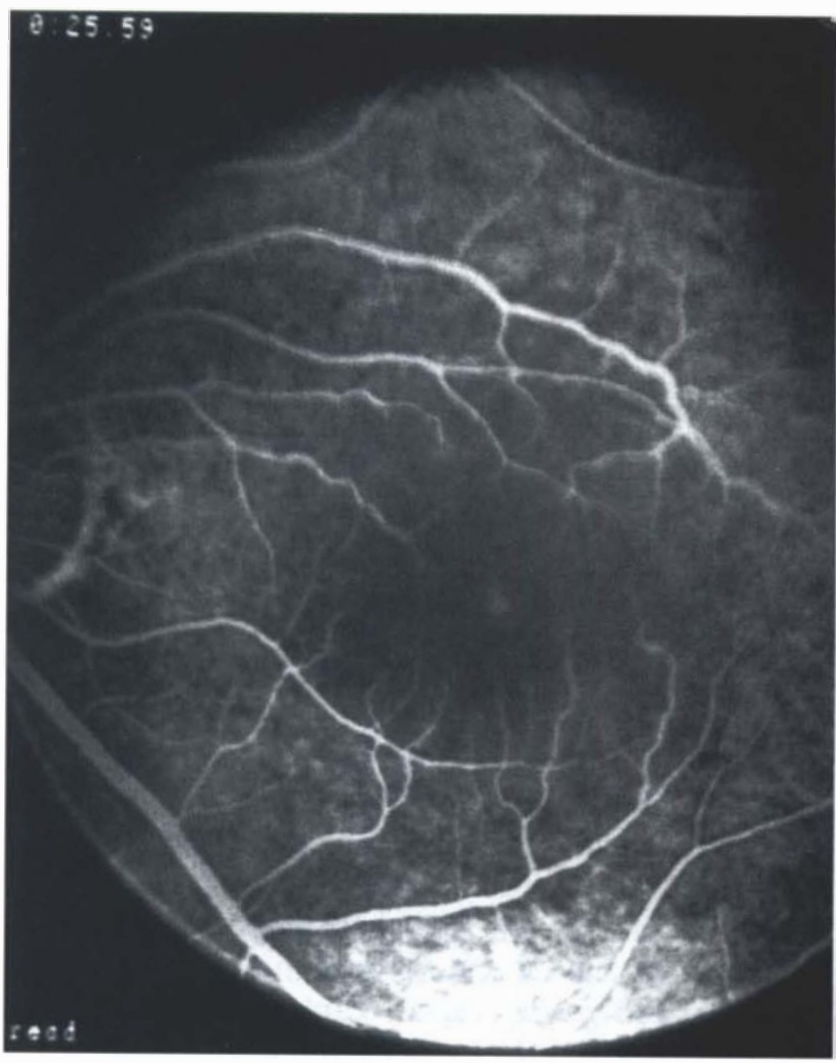

(b)

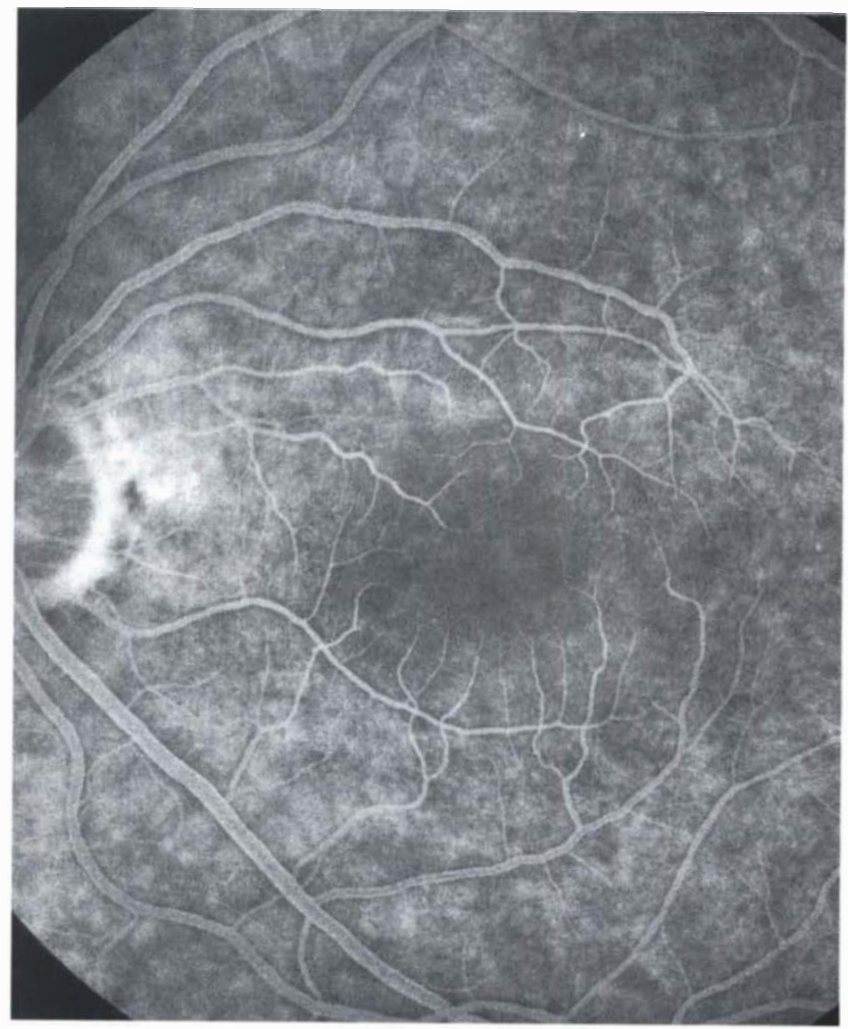

(d)

Fig. 1. Fundus photograph (a) and fluorescein angiogram (b) of a patient with stage II full-thickness macular hole (FTMH) presenting 2 weeks after the onset of symptoms. Note the transmission defect on the fluorescein angiogram corresponding to the FTMH. The visual acuity is 6/24. In the fundus photograph (c) and fluorescein angiogram (d) of the same eye after vitrectomy and partial fluid $/ S F_{6}$ gas exchange the hole is no longer visible and there is no transmission defect on the angiogram. The visual acuity is 6/9. 


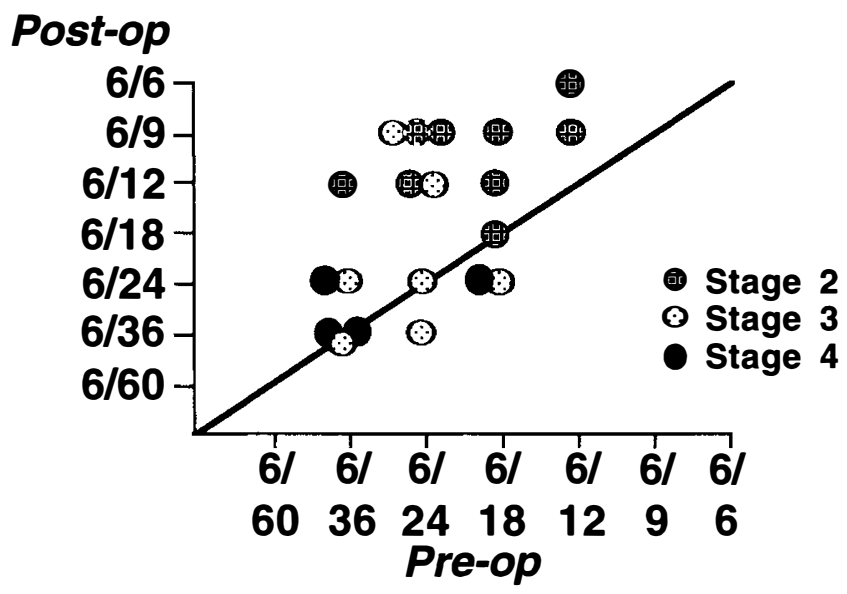

Fig. 2. The visual change after early vitrectomy and partial fluid $/ S F_{6}$ gas exchange for FTMH (stages II-IV).

with stage III holes and none of the 4 patients with stage IV holes (Fig. 1). The change in the best corrected visual acuity reflected the closure rate of FTMH. Of the 9 patients with stage II holes, $6(67 \%)$ had visual improvement, whereas only 2 of the 7 (29\%) with stage III and none of the 4 with stage IV had improved vision (Fig. 2; Table II).

It appeared that the earlier patients presented with early stages of FTMH, the better the visual results that could be obtained. Of the patients who presented within 3 weeks after the onset of symptoms, 7 improved by 2 Snellen lines or more, while only 1 patient who presented after 3 weeks did so. Visual acuity of 6/12 or better was obtained in 6 of 8 patients who presented within 3 weeks, but the same was true of only 4 of the 12 with later presentation (Table III). Thus the favourable pre-operative characteristics were a shorter duration of symptoms and a smaller sized hole; this is in agreement with the results obtained in subsequent studies. ${ }^{23}$

\section{ADJUNCTIVE SUBSTANCES IN MACULAR HOLE SURGERY}

Whereas smaller (stage II) FTMHs may be closed by a relatively simple surgical procedure, additional steps may be required for the treatment of the later stages of FTMH (stages III and IV). In 1992, Glaser et $a .^{14}$ reported excellent results using bovine transforming growth factor beta (TGF- $\beta$ ) in conjunction with vitrectomy and gas tamponade. ${ }^{14}$ TGF- $\beta$ had previously been shown to be a potent stimulator of the synthesis of collagen and glycoprotein, as well

Table II. Early vitrectomy for FTMH with partial $\mathrm{SF}_{6}$ gas tamponade $(n=20)$ : anatomical and visual results

\begin{tabular}{lccc}
\hline & Stage II & Stage III & Stage IV \\
\hline Closure of FTMH & $8 / 9$ & $2 / 7$ & $0 / 4$ \\
Visual improvement & $6 / 9$ & $2 / 7$ & $0 / 4$ \\
$\quad$ (2 Snellen lines) & & & \\
\hline
\end{tabular}

FTMH, full-thickness macular holes.
Table III. Early vitrectomy for FTMH with partial $\mathrm{SF}_{6}$ gas tamponade $(n=20)$ : visual results and duration of symptoms

\begin{tabular}{lcc}
\hline & $\begin{array}{c}\text { Presentation at } \\
<3 \text { weeks }\end{array}$ & $\begin{array}{c}\text { Presentation at } \\
>3 \text { weeks }\end{array}$ \\
\hline $\begin{array}{l}\text { Visual improvement } \\
\begin{array}{c}\text { (2 Snellen lines) } \\
\text { Visual acuity better than 6/12 }\end{array}\end{array}$ & $7 / 8$ & $1 / 8$ \\
\hline
\end{tabular}

as of cell proliferation and migration, and to promote chorioretinal adhesion. ${ }^{24}$ Using $1330 \mathrm{ng}$ of bovine TGF- $\beta$, Lansing et al. ${ }^{25}$ achieved overall closure of FTMH in $96 \%$ of 23 eyes with visual improvement in $85 \%$. However, in a subsequent study where recombinant TGF- $\beta$ was used the closure rate decreased to $77 \%,{ }^{26}$ suggesting that an immunological reaction to bovine TGF may have contributed to some extent to the higher closure rate reported previously. ${ }^{14.25}$

Using autologous serum Liggett et al. ${ }^{15}$ achieved a closure rate of FTMH comparable to that achieved with bovine TGF- $\beta$. Serum is known to contain an array of growth factors and is a chemoattractant for glia, retinal pigment epithelial cells and fibroblasts. It also encourages cell migration and proliferation and chorioretinal adhesion. ${ }^{27}$ Serum has the added advantage that, unlike TGF- $\beta$, it is easily obtainable. Encouraging results of vitrectomy with autologous serum have also been reported by $\mathrm{us}^{28}$ and others. ${ }^{29}$

Platelets are another potent source of growth factors and platelet extracts have been shown to promote healing. ${ }^{30.31}$ Using autologous platelet concentrate, Gaudric et al. ${ }^{32}$ have reported impressive results in a pilot study of 20 eyes, obtaining $95 \%$ closure of FTMH. The use of other adjunctive substances such as the mixture of autologous plasma and thrombin, ${ }^{33}$ Tissucol $^{34}$ (Tissucol Duo 500, Immuno AG, Vienna) and fibrin ${ }^{35}$ is also promising, with reported anatomical successes of $77 \%, 84 \%$ and $84 \%$ respectively (Table IV).

It appears that closure of a FTMH is associated with a limited healing response. Proliferation of fibrous astrocytes ${ }^{36}$ and Müller cells ${ }^{37}$ has been demonstrated in histological studies of successfully treated eyes with FTMH. ${ }^{5}$ Such a limited healing response may be encouraged by the use of adjunctive

Table IV. Reported results of surgery for FTMH

\begin{tabular}{|c|c|c|}
\hline Authors & Adjunctive substance & $\begin{array}{l}\text { Closure of } \\
\text { FTMH }\end{array}$ \\
\hline Kelly and Wendel ${ }^{13}$ & - & $52 \%$ \\
\hline Glaser et al. ${ }^{14}$ & Bovine TGF- $\beta$ & $100 \%$ \\
\hline Thompson et al. ${ }^{26}$ & Recombinant TGF- $\beta$ & $77 \%$ \\
\hline Liggett et al. & Autologous serum & $89 \%$ \\
\hline Blumenkranz et al. ${ }^{33}$ & $\begin{array}{c}\text { Autologous plasma and } \\
\text { thrombin }\end{array}$ & $77 \%$ \\
\hline Tilanus and Deutman ${ }^{34}$ & Tissucol & $84 \%$ \\
\hline Iwasaki et al. ${ }^{35}$ & Autologous fibrin & $84 \%$ \\
\hline Gaudric et al. ${ }^{32}$ & $\begin{array}{l}\text { Autologous platelet } \\
\text { concentrate }\end{array}$ & $95 \%$ \\
\hline Wendel et al. $^{19}$ & - & $93 \%$ \\
\hline
\end{tabular}


substances, such as autologous serum and the growth factors they contain. While this is a new and exciting development in ophthalmology, our enthusiasm must be tempered by the fact that other authors report similar results with vitrectomy and gas tamponade with strict post-operative face down positioning alone $^{19}$ (Table IV). Controlled randomised treatment trials designed to assess the usefulness of the various healing promoters are now in progress and we must await their results before deciding on the best treatment for our patients with FTMHs.

Key words: Macular hole, Vitrectomy, Cellular proliferation.

\section{REFERENCES}

1. Aaberg TM, Blair CJ, Gass JDM. Macular holes. Am J Ophthalmol 1970;69:555-62.

2. James M, Feman SS. Macular holes. Graefes Arch Clin Exp Ophthalmol 1980;215:59-63.

3. The Eye Disease Case-Control Study Group. Risk factors for idiopathic macular holes. Am J Ophthalmol 1994;118:754-61.

4. Trempe CL, Weiter JJ, Furukawa H. Fellow eyes in cases of macular hole: biomicroscopic study of the vitreous. Arch Ophthalmol 1986;104:93-5.

5. Hikichi T, Akiba J, Trempe CL. Effect of the vitreous on the prognosis of full-thickness idiopathic macular holes. Am J Ophthalmol 1993;116:273-8.

6. Gass JDM. Idiopathic senile macular hole: its early stages and pathogenesis. Arch Ophthalmol 1988;106:629-39.

7. de Bustros S. Vitrectomy for prevention of macular holes: results of a randomised multicentre clinical trial. Ophthalmology 1994;101:1055-9.

8. Akiba J, Yoshida A, Trempe CL. Risk of developing a macular hole. Arch Ophthalmol 1990;108:1088-90.

9. Fisher YL, Slakter JS, Yannuzzi LA, Guymer DR. A prospective natural history study and kinetic ultrasound evaluation of idiopathic macular holes. Ophthalmology 1994;101:5-11.

10. Smiddy WE, Michels RG, Glaser BM, de Bustros S. Vitrectomy for impending idiopathic macular holes. Am J Ophthalmol 1988;105:371-6.

11. Jost BF, Hutton WL, Fuller DG, Vaiser A, Snyder WB, Fish GE, et al. Vitrectomy in eyes at risk for macular hole formation. Ophthalmology 1990;97:843-7.

12. Orr GM, Gregor ZJ. Surgery for impending macular holes. Unpublished data presented at the 1993 Congress of the Royal College of Ophthalmologists.

13. Kelly NE, Wendel RT. Vitreous surgery for idiopathic macular holes: results of a pilot study. Arch Ophthalmol 1991;109:654-9.

14. Glaser BM, Michels RG, Kuppermann BD, Sjaarda RN, Pena RA. Transforming growth factor beta-2 for the treatment of full-thickness macular holes. Ophthalmology 1992;99:1162-73.

15. Liggett PE, Skolik SA, Horio B, Saito Y, Alfrao DV, Mieler WF. Human autologous serum for the treatment of full-thickness macular holes. Ophthalmology 1995;102:1071-6.

16. Patel AC, Wendel RT. Vitrectomy for macular hole. Semin Ophthalmol 1994;9:47-55.

17. Ruby AJ, Williams DF, Grand MG, Thomas MA,
Meredith TA, Boniuk I, Olk RJ. Pars plana vitrectomy for treatment of Stage 2 macular holes. Arch Ophthalmol 1994;112:359-64.

18. Gregor ZJ, Orr GM. Vitrectomy and fluid gas exchange for early full-thickness macular holes. Retina Society, 25th Annual Meeting, 1992: 107.

19. Wendel RT, Patel AC, Kelly NE, Salzano TC, Wells JW, Novack GD. Vitreous surgery for macular holes. Ophthalmology 1993;100:1671-6.

20. Guyer DR, de Bustros S, Diener-West M, Fine SL. Observations on patients with idiopathic macular holes and cysts. Arch Ophthalmol 1992;95:917-24.

21. Lewis H, Cowan GM, Straatsma BR. Apparent disappearance of a macular hole associated with development of an epiretinal membrane. Am J Ophthalmol 1986;102:172-5.

22. Guyer DR, Green WR, de Bustros S, Fine SL. Histopathologic features of idiopathic macular holes and cysts. Ophthalmology 1990;97:1045-51.

23. Ruby AJ, Williams DF, Grand G, Thomas MA, Meredith TA, Boniuk I, Olk J. Pars plana vitrectomy for treatment of Stage 2 macular holes. Arch Ophthalmol 1994;112:359-64.

24. Smiddy WE, Glaser BM, Green R, Connor TB, Roberts AB, Lucas R, Sporn MB. Transforming growth factor beta: a biologic chorioretinal glue. Arch Ophthalmol 1989;107:577-80.

25. Lansing MB, Glaser BM, Liss H, Hanham A, Thompson JT, Sjaarda RN, Gordon AJ. The effect of pars plana vitrectomy and transforming growth factor beta-2 without epiretinal membrane peeling on fullthickness macular holes. Ophthalmology 1993; 100:868-72.

26. Thompson JT, Smiddy WE, Williams GA, Sjaarda RN, Flynn HW, Margherio RR, et al. Comparison of recombinant TGF- $\beta_{2}$ and placebo at three months in the treatment of macular holes. The Macular Society, 18th Annual Meeting 1995:110.

27. Christmas NJ, Skolik SA, Howard MA, Saito Y, Barnstable CJ, Liggett PE. Treatment of retinal breaks with autologous serum in an experimental model. Ophthalmology 1995;102:263-71.

28. Wells JA, Gregor ZJ. Surgical treatment of macular holes using autologous serum. Eye 1996;10:593-9.

29. Garcia-Arumi J, Corcostegui B, Mateo C, Adan A, Salvador F. Surgical management of idiopathic macular holes by vitrectomy and autologous serum. Communication to Club Jules Gonin, Versailles, September 1994.

30. Hitaizumi Y, Transfeldt EE, Kawahara N, Sung JH, Knighton $\mathrm{D}$, Fiegel $\mathrm{VD}$. In vitro angiogenesis by platelet-derived wound-healing formula in injured spinal cord. Brain Res Bull 1993;30:353-7.

31. Ksander GA, Sawamura S, Ohawa Y, Sundsmo J, McPherson $\mathbf{J}$. The effect of platelet release on wound healing in animal models. J Am Acad Dermatol 1990;22:781-91.

32. Gaudric A, Massin P, Paques M, Santiago PY, Guez $\mathrm{JE}$, La Gargasson JF, et al. Autologous platelet concentrate for the treatment of full-thickness macular holes. Graefes Arch Clin Exp Ophthalmol 1995;233: 549-54.

33. Blumenkranz MS, Coll GE, Chang S, Morse LS. Use of autologous plasma-thrombin mixture as adjuvant therapy for macular hole. Ophthalmology 1994;101(Suppl):769.

34. Tilanus M, Deutman AF. Treatment of macular holes with Tissucol. Communication to Club Jules Gonin, Versailles, September 1994. 
35. Iwasaki T, Sanada A, Yamamoto K, Okade A, Usui NM. The use of fibrin tissue adhesive in the treatment of macular holes. Invest Ophthalmol Vis Sci 1995;36:1050.

36. Funata M, Wendel RT, de la Cruz Z, Green WR. Clinicopathologic study of bilateral macular holes treated with pars plana vitrectomy and gas tamponade. Retina 1992;12:289-98.

37. Madraperla SA, Geiger GL, Funata M, de la Cruz Z, Green R. Clinicopathologic correlation of a macular hole treated by cortical vitreous peeling and gas tamponade. Ophthalmology 1994;11:611-3. 